\title{
Impact of Railway Noise on People Based on Strategic Acoustic Maps
}

\author{
Marcin Wrótny *(1) and Janusz Bohatkiewicz \\ Department of Roads and Bridges, Faculty of Civil Engineering and Architecture, Lublin University of \\ Technology, Nadbystrzycka 40, 20-618 Lublin, Poland; j.bohatkiewicz@pollub.pl \\ * Correspondence: m.wrotny@pollub.pl
}

Received: 20 June 2020; Accepted: 10 July 2020; Published: 13 July 2020

\begin{abstract}
The main objectives of the introduced Directive 2002/49/EC are to harmonize the activities intended to control the harmful effects of noise pollution and to standardize the methodology for their assessment. Strategic acoustic maps drawn up in the EU Member States allow for determining the state of environmental noise pollution and planning preventive measures. This study involved analyses of noise levels in selected European capitals and Polish cities. The number of inhabitants who may be affected by a high degree of sleep disturbance caused by railway noise was also analyzed. An attempt was made to present a correlation between the scale of noise exposure and population density, the length of the existing railway infrastructure, and the type of areas with railways running through them. The most unfavorable type of development in terms of the number of people exposed to noise is compact development located directly along railway lines. Thanks to the acoustic maps, it is possible to locate the most noise-polluted places and establish a hierarchy of protective measures.
\end{abstract}

Keywords: railway noise; acoustic maps; noise impact on people; environmental noise pollution

\section{Introduction}

The phenomenon of noise is a well-known, negative influence, which accompanies people in their everyday life. It causes negative feelings such as dissatisfaction, anxiety, irritation, and excessive noise effect can lead to conditions such as hypertension [1], reduced functional performance, sleep difficulties [2-6], and even hearing loss [7].

The European Parliament and the Council of the European Union adopted Directive 2002/49/EC relating to the assessment and management of environmental noise in 2002. The main objectives of this Directive are to define a common approach to avoiding, preventing, or reducing the harmful effects of exposure to noise, including annoyance, and to harmonize the noise risk assessment methodology [8-11].

Directive deals with environmental noise, i.e., undesirable sounds caused by human activity, in particular noise generated by transport in the broad sense, and noise from industrial activities.

All Member States of the European Union are obliged to make strategic noise maps every five years for all agglomerations with more than 100,000 inhabitants. In addition, the program must also cover all roads with more than 3 million vehicles a year, major railways with over 30,000 trains a year, as well as major airports in the country. These figures were determined in 2011, and they were reduced from 6 million vehicles and 60,000 trains, respectively, meaning an increase in the scope of the analyzed traffic routes [12].

The environmental noise is determined using basic noise indicators, which are physical scales associated with the harmful effect. These include: $\mathrm{L}_{\text {den }}\left(\mathrm{L}_{\mathrm{DWN}}\right), \mathrm{L}_{\text {day }}\left(\mathrm{L}_{\mathrm{D}}\right), \mathrm{L}_{\text {evening }}\left(\mathrm{L}_{W}\right)$, and $\mathrm{L}_{\text {night }}$ $\left(\mathrm{L}_{\mathrm{N}}\right)$ (these indicators are described in the further part of the article in formula 1) [8]. The individual 
indicators will be explained in the further part of the text. Both $\mathrm{L}_{\mathrm{DWN}}$ and $\mathrm{L}_{\mathrm{N}}$ indicators are applicable to long-term environmental noise policy.

Thanks to the Directive [8], strategic noise maps have been developed in many European cities. Unfortunately, the acoustic maps provided by the European Environment Agency are not complete from every country [13].

Measurements for acoustic maps are made in order to verify the calculation model. The Directive does not specify the methodology for preparing maps, listing only the conditions they are supposed to contain. After the first stage of acoustic mapping in 2007, the European Commission assessed the comparability of the results. These assessments showed that it is difficult to provide figures from Member States that would allow for consistently comparing of the numbers of people exposed to excessive noise. Therefore, Common Noise Assessment Methods (CNOSSOS-EU) for environmental noise have been developed for road, rail, air, and industrial traffic, which have been implemented since 2017 [14].

Based on analyzing railway transport in Europe, the rolling stock is highly diverse. The countries of Central and Eastern Europe are only just upgrading their railway infrastructure. However, over time, the rolling stock in each country will be very similar, which is why the aforementioned CNOSSOS study introduces a division into eight types of railway vehicles and takes into account additional vehicle design aspects, such as number of axles, type of braking system, and wheel measure.

\section{Materials and Methods}

Most often, in national standards, traffic noise generated by road and rail traffic is assessed in terms of sound pressure level, taking the A frequency correlation into account. It corresponds to the characteristics of the human hearing threshold, i.e., reflects low sensitivity to low frequencies. $[15,16]$. The directive [8] describes how to determine the $\mathrm{L}_{\mathrm{DWN}}$ indicator according to the following formula:

$$
L_{D W N}=10 \lg \left[\frac{12}{24} 10^{0,1 L_{D}}+\frac{4}{24} 10^{0,1\left(L_{W}+5\right)}+\frac{8}{24} 10^{0,1\left(L_{N}+10\right)}\right]
$$

where:

$\mathrm{L}_{\mathrm{DWN}}$ means the long-term mean A-weighted sound level expressed in decibels $(\mathrm{dB})$, determined over all days of the year, taking into account day time (understood as the period from 6:00 am to 6:00 pm), evening time (understood as the period from 6:00 pm to 10:00 pm), and night time (understood as the period from 10:00 $\mathrm{pm}$ to $6: 00 \mathrm{am}$ ),

$\mathrm{L}_{\mathrm{D}}$ means the long-term mean A-weighted sound level expressed in decibels $(\mathrm{dB})$, determined over all the day time periods of the year,

$\mathrm{L}_{\mathrm{W}}$ means the long-term mean A-weighted sound level expressed in decibels $(\mathrm{dB})$, determined over all the evening time periods of the year,

$\mathrm{L}_{\mathrm{N}}$ means the long-term mean A-weighted sound level expressed in decibels ( $\mathrm{dB}$ ), determined over all the night time periods of the year.

For analyses relating to one day, the acoustic calculations are made using other indicators, i.e., $\mathrm{L}_{\mathrm{AeqD}}$ (equivalent sound level during the daytime -6 am to $10 \mathrm{pm}$ ) and $\mathrm{L}_{\mathrm{AeqN}}$ (equivalent sound level during the nighttime- $10 \mathrm{pm}$ to $6 \mathrm{am}$ ).

An assessment of traffic noise effect on humans, based only on the noise limit values makes it impossible to determine the actual risk. There is a number of complementary indicators that show the harmful effects of long-term noise on the health of inhabitants. The END Directive recommends the use of dose-effect indicators [5,6], however, they are defined only as general provisions.

European Environmental Agency and World Health Organization [5,6] presents indicators that illustrate the effects of noise on humans, taking into account various health aspects, such as sleep disorders [17,18], annoyance [1,19], hypertension, and even ischemic heart disease [1,2].

Noise annoyance is one of the negative effects of noise on people. The percentage of people affected by noise annoyance $(\% \mathrm{D}, \% \mathrm{WD})$ can be determined using the basic $\mathrm{L}_{\mathrm{DWN}}$ indicator [20]. 
The calculation formulas that are described in Equations (2)-(5), vary depending on the type of traffic noise in question.

When analyzing road noise, the percentage of people affected can be calculated from the formula $[5,21]$ :

$$
\% D=1.795 * 10^{-4}\left(L_{D W N}-37\right)^{3}+2.110 * 10^{-2}\left(L_{D W N}-37\right)^{2}+0.5353\left(L_{D W N}-37\right)[\%]
$$

while the percentage of people affected by high noise annoyance from the formula:

$$
\% W D=9.868 * 10^{-4}\left(L_{D W N}-42\right)^{3}-1.436 * 10^{-2}\left(L_{D W N}-42\right)^{2}+0.5118\left(L_{D W N}-42\right)[\%]
$$

In case of railway noise, the forgoing formulas are [5,21]:

$$
\begin{aligned}
& \% D=4.538 * 10^{-4}\left(L_{D W N}-37\right)^{3}+9.482 * 10^{-2}\left(L_{D W N}-37\right)^{2}+0.2129\left(L_{D W N}-37\right)[\%] \\
& \% W D=7.239 * 10^{-4}\left(L_{D W N}-42\right)^{3}-7.851 * 10^{-2}\left(L_{D W N}-42\right)^{2}+0.1695\left(L_{D W N}-42\right)[\%]
\end{aligned}
$$

The foregoing indicators result from the transformation of different noise annoyance scales with the application of limit values. The model of noise annoyance distribution with normative distribution and very accurate mathematical analyses are shown in [19]. The presented polynomial approximations are easier to use than the accurate equations including normal distribution formulae and are sufficiently accurate for practical purposes [22].

Another one of the most unfavorable noise effects is its impact on the sleep of inhabitants [23]. Sleep deprivation or disturbances can result in poor mood, irritation, as well as problems with focus. The sleep disorder indicator determines the percentage of people with sleep disorders and is dependent on the $\mathrm{L}_{\mathrm{N}}$ indicator. Similarly to the previously discussed indicator, it also depends on the traffic noise in question.

Based on [23], the percentage of people affected by sleep disorders caused by road noise is described by the formula:

$$
\% \text { ZS }=13.8-0.85 L_{N}+0.01670 L_{N}^{2}[\%]
$$

and the percentage of people with high sleep disturbances is:

$$
\% W Z S=20.8-1.05 L_{N}+0.01486 L_{N}^{2}[\%]
$$

The analogous formulas for railway noise are the following:

$$
\begin{gathered}
\% Z S=12.5-0.66 L_{N}+0.01121 L_{N}^{2}[\%] \\
\% W Z S=11.3-0.55 L_{N}+0.00759 L_{N}^{2}[\%]
\end{gathered}
$$

In most cases, the indicators concerning the noise limit values in accordance with the regulations are used in practice [24,25]. In accordance with the Minister's Regulation [12], in the environmental noise protection programs for cities in Poland, it is necessary to evaluate the applied methods and measures of noise protection, as well as to decide on the sequence of undertaken actions. Here, the $\mathrm{M}$ indicator plays an important role, which characterizes the excess of the reference noise level and the number of inhabitants in the area where the excess occurs. In practice, based on the prepared maps and the $\mathrm{M}$ indicator, schedules of remedial actions are created and the qualification of areas for which these actions should be undertaken in the first place is determined. The higher the value of the M-indicator, the faster the reaction should be, with adequate noise protection.

It is established as follows:

$$
M=0.1 m\left(10^{0.1 \Delta L}-1\right)[-]
$$

where: 
$\mathrm{M}-$ value of the indicator [-],

$\Delta \mathrm{L}$ - the size of excess above the permissible noise level [dB],

$\mathrm{m}$-the number of inhabitants in the area with the exceeded level [number of people].

The M-indicator can be calculated using the formula given above, but the Regulation [12] does not provide detailed guidance as to whether the parameter should be calculated for buildings, noise-affected areas, or a certain section of traffic route or land area [21]. Such a vagueness results in problems with interpreting this indicator, and thus problems in establishing appropriate corrective actions.

Directive [8] recommends providing an estimate of the number of people exposed to noise within the following ranges of $\mathrm{L}_{\mathrm{DWN}}[\mathrm{dB}]$ : 55-59, 60-64, 65-69, 70-74, $>75$, separately for each noise type (road, rail, air, industrial). For $\mathrm{L}_{\mathrm{N}}$ values, the ranges are as follows: 50-54, 55-59, 60-64, 65-69, >70. The number of inhabitants in each range is rounded up to the next hundred. Below, data on European and Polish agglomerations will be analyzed with a breakdown into road and rail noise, taking into account the aforementioned ranges. The END Directive [8] does not directly set admissible values for noise levels, but according to the information indicated on the website of the European Environment Agency [26], a $\mathrm{L}_{\mathrm{DWN}}$ limit value of $55 \mathrm{~dB}$ per day and $\mathrm{L}_{\mathrm{N}}$ value of $50 \mathrm{~dB}$ per night may be adopted [26].

The data analyzed later in this article are derived from measurements taken in 2017. Directive [8] only sets out general requirements that each Member State should comply with, while the research methods are laid down in national regulations. In Poland, measurements should be carried out in accordance with the regulations contained in the Regulation of the Minister of Environment [27]. A full review of the noise pollution situation in road and rail traffic was carried out in about 300 European agglomerations. The research also covered more than $420,000 \mathrm{~km}$ of main roads (more than 3 million vehicles per year) and 50,000 $\mathrm{km}$ of railway lines (more than 30,000 trains per year).

Nine European capitals, each having more than 1 million inhabitants, and 10 Polish agglomerations with more than 250,000 inhabitants were selected for further analyses as a part of this article. These cities were listed together with demographic data in Table 1 (European) and Table 2 (Polish).

Table 1. Selected European agglomerations where acoustic maps have been made.

\begin{tabular}{cccc}
\hline Country & City & Number of Inhabitants & Total Area of the City [km $\mathbf{k m}^{\mathbf{}]}$ \\
\hline Austria & Vienna & $1,862,251$ & 459 \\
Bulgaria & Sofia & $1,332,817$ & 492 \\
Czech Republic & Prague & $1,234,005$ & 772 \\
France & Paris & $7,068,800$ & 814 \\
Germany & Berlin & $3,460,725$ & 892 \\
Hungary & Budapest & $2,158,871$ & 1130 \\
Ireland & Dublin & $1,308,900$ & 936 \\
Poland & Warsaw & $1,753,977$ & 517 \\
Great Britain & London & $9,878,000$ & 1623 \\
\hline
\end{tabular}

Table 2. Selected Polish agglomerations where acoustic maps have been made.

\begin{tabular}{ccc}
\hline City & Number of Inhabitants & Total Area of the City $\left[\mathbf{k m}^{\mathbf{2}}\right]$ \\
\hline Warsaw & $1,753,977$ & 517 \\
Cracow & 766,739 & 327 \\
Łódź & 701,410 & 293 \\
Wrocław & 631,377 & 293 \\
Poznań & 509,436 & 263 \\
Gdańsk & 463,764 & 262 \\
Lublin & 340,200 & 147 \\
Bydgoszcz & 329,188 & 176 \\
Białystok & 296,600 & 102 \\
Katowice & 296,262 & 165 \\
\hline
\end{tabular}




\section{Results}

\subsection{European Agglomerations}

\subsubsection{Road Noise}

Road noise is one of the biggest environmental problems and the data in Table 3 show how big the scale is. Table 3 shows the percentage of the population in selected European capitals exposed to road traffic noise by relevant ranges, distinguishing between $\mathrm{L}_{\mathrm{DWN}}$ and $\mathrm{L}_{\mathrm{N}}$ indicators.

Table 3. Population in selected European capitals exposed to road noise, with a distinction between $\mathrm{L}_{\mathrm{DWN}}$ and $\mathrm{L}_{\mathrm{N}}$ indicators.

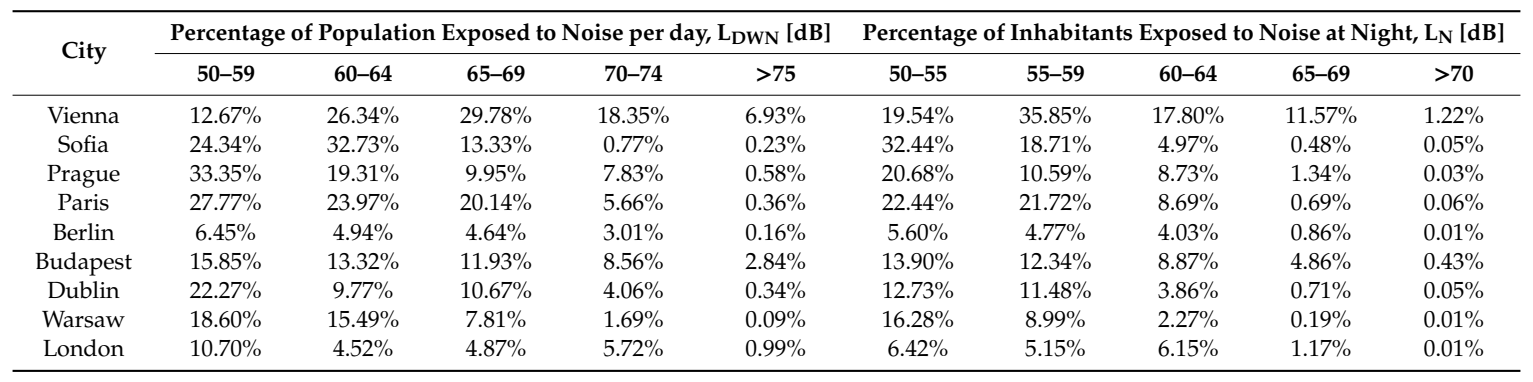

Vienna is a city in which the percentage of the population exposed to noise exceeding the admissible limit value is the highest among the analyzed agglomerations. More than $80 \%$ of the inhabitants, those working both in day and night time, are not protected against road noise. Four cities with percentages in the 30-60\% range can be distinguished based on the chart, and these include: Sofia, Paris, Prague, and Budapest. In contrast, capitals such as Dublin, Warsaw, and London are much less polluted by noise originating from the vehicle traffic, and the percentage of inhabitants exposed to road noise is less than 30\% It should be noted that in Berlin, the percentage of people exposed to noise exceeding the admissible level is the lowest, at around $10 \%$

\subsubsection{Railroad Noise}

Analyzing the railway noise data [13], it can be concluded that the number of people affected by this negative factor is lower compared to the traffic noise. This conclusion is confirmed by the results of the studies presented in Table 4.

Table 4. Population in selected European capitals exposed to railroad noise, with a distinction between $\mathrm{L}_{\mathrm{DWN}}$ and $\mathrm{L}_{\mathrm{N}}$ indicators.

\begin{tabular}{|c|c|c|c|c|c|c|c|c|c|c|}
\hline \multirow{2}{*}{ City } & \multicolumn{5}{|c|}{ Percentage of Population Exposed to Noise per day, $L_{D W N}[d B]$} & \multicolumn{5}{|c|}{ Percentage of Inhabitants Exposed to Noise at Night, $\mathrm{L}_{\mathrm{N}}[\mathrm{dB}]$} \\
\hline & $50-59$ & $60-64$ & $65-69$ & $70-74$ & $>75$ & $50-55$ & $55-59$ & $60-64$ & $65-69$ & $>70$ \\
\hline Vienna & $11.77 \%$ & $9.65 \%$ & $2.78 \%$ & $1.11 \%$ & $0.54 \%$ & $12.23 \%$ & $4.86 \%$ & $1.92 \%$ & $0.86 \%$ & $0.21 \%$ \\
\hline Paris & $5.97 \%$ & $3.18 \%$ & $1.78 \%$ & $0.73 \%$ & $0.25 \%$ & $5.01 \%$ & $2.59 \%$ & $1.37 \%$ & $0.57 \%$ & $0.15 \%$ \\
\hline Berlin & $2.91 \%$ & $1.77 \%$ & $0.87 \%$ & $0.18 \%$ & $0.03 \%$ & $2.38 \%$ & $1.31 \%$ & $0.52 \%$ & $0.09 \%$ & $0.01 \%$ \\
\hline Budapest & $3.00 \%$ & $1.19 \%$ & $0.43 \%$ & $0.09 \%$ & $0.00 \%$ & $2.20 \%$ & $0.85 \%$ & $0.31 \%$ & $0.05 \%$ & $0.00 \%$ \\
\hline London & $2.48 \%$ & $1.72 \%$ & $1.09 \%$ & $0.51 \%$ & $0.19 \%$ & $1.98 \%$ & $1.35 \%$ & $0.73 \%$ & $0.28 \%$ & $0.07 \%$ \\
\hline
\end{tabular}

As in the case of road noise, in first place we have the capital of Austria, Vienna, which is the city with the highest percentage of inhabitants exposed to railway noise. However, the values of these parameters must be taken into account. The percentage of the population in Vienna exposed to noise from train traffic does not exceed $20 \%$, and it is lower than $10 \%$ in other agglomerations. It is worth noting that when analyzing the road noise, the value of $10 \%$ is the lowest indicator of the analyzed 
European capitals. It can be clearly stated that railway noise constitutes a much lower environmental threat than road noise $[5,6]$.

People living in areas close to busy streets and areas surrounded by railway lines often complain about disturbances in direct communication, yet sleep disturbances caused by noise are much more harmful. Using formulas $(6,7)$, it is possible to determine the number of inhabitants whose sleep may be interrupted by railway noise affecting them. This issue is important, as this problem may contribute to the development of cardiovascular diseases in the long run. Figure 1 clearly shows that the number of people exposed to high levels of sleep disturbance in cities such as Paris, London, Vienna is the highest in comparison to the other agglomerations analyzed. In Paris, over 30,000 inhabitants may suffer from sleep problems caused by the effect of train traffic noise, with over 20,000 in London, and less than 16,000 in Vienna. The smallest number of people living in the analyzed cities is affected by this problem in the Polish capital. In Warsaw, only less than 300 people are exposed to a high level of sleep disturbance caused by railway noise.

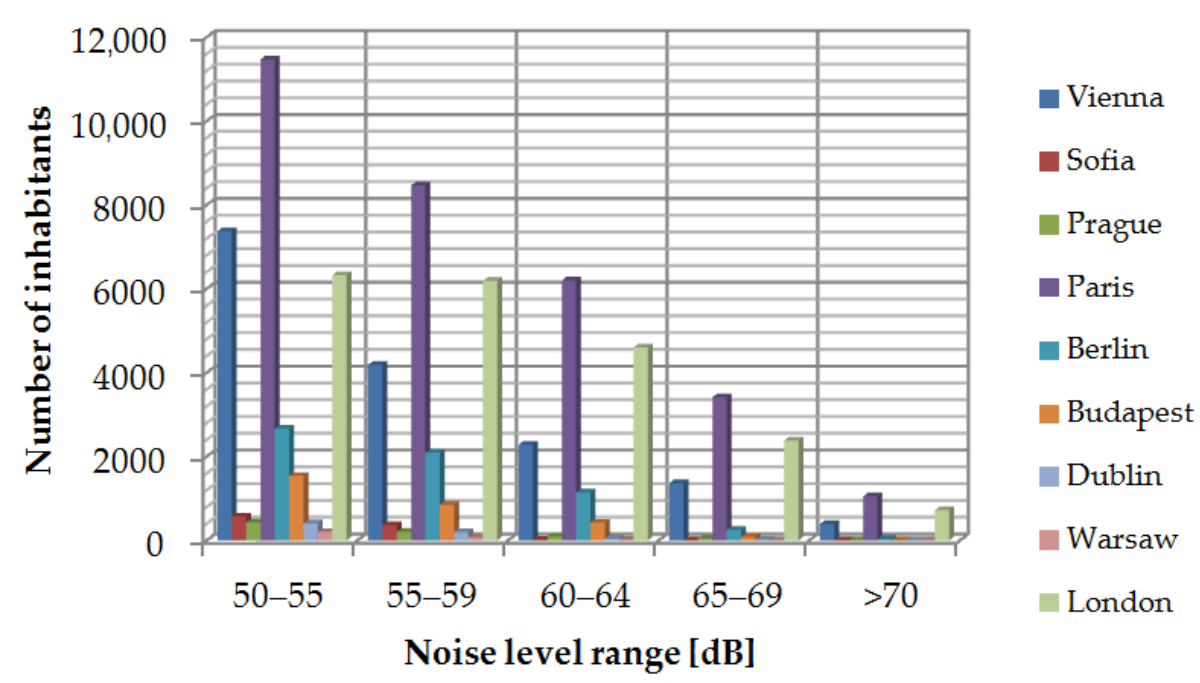

Figure 1. Population exposed to high levels of sleep disturbance caused by railway noise in selected European agglomerations.

Based on the data contained in Table 4, the mean values of the M indicator, as described in Equation (10), were also calculated for each of the noise level ranges. In addition, the population density in individual capitals was also taken into account. Due to the fact that this indicator depends mainly on the number of inhabitants exposed to noise higher than the permissible level, the highest values are reached in Paris and London. Figure 2 shows the values of the $\mathrm{M}$ indicator for particular ranges and additionally the population density for specific capitals. It can be seen that the highest $\mathrm{M}$-values are achieved in Paris and London. The population density in these two cities is also the highest among the analyzed agglomerations. The lowest M-values are present in Sofia, Prague, Dublin, and Warsaw. The population density in this group of capitals does not exceed 3000 people $/ \mathrm{km}^{2}$. 

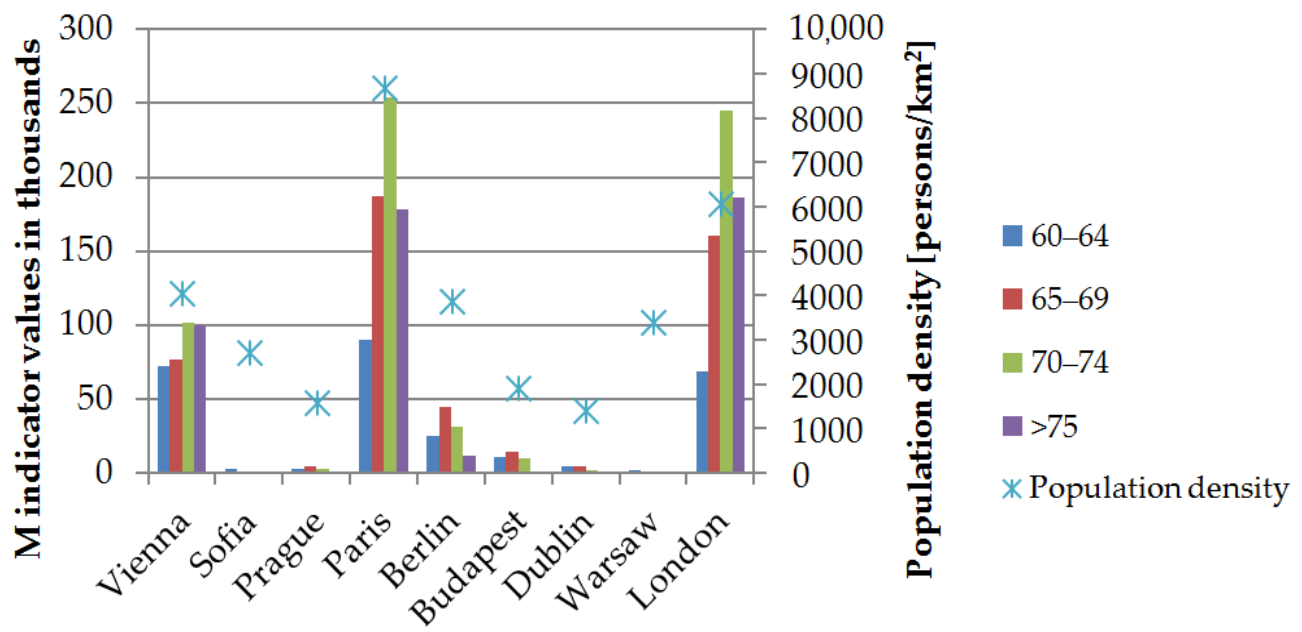

European agglomeration

Figure 2. Comparison of the $\mathrm{M}$ indicator for rail noise in selected European capitals, taking into account the population density in these cities.

\subsection{Polish Agglomerations}

\subsubsection{Road Noise}

Just like in Europe, traffic noise is a big environmental problem in Poland. Table 5 shows the percentage of inhabitants in selected Polish cities exposed to road noise, with a distinction between $\mathrm{L}_{\mathrm{DWN}}$ and $\mathrm{L}_{\mathrm{N}}$ indicators.

Table 5. Population in selected European capitals exposed to railroad noise, with a distinction between $\mathrm{L}_{\mathrm{DWN}}$ and $\mathrm{L}_{\mathrm{N}}$ indicators.

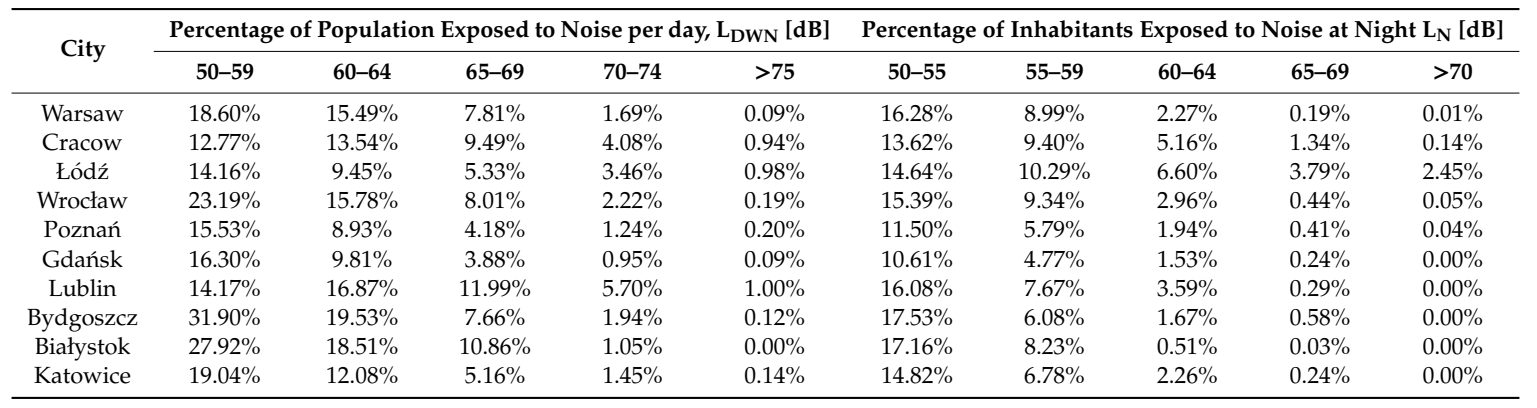

The data in Table 5 show the percentage of people exposed to road noise in selected Polish cities. The lowest percentage is in Poznań and is lower than 15\% Similar values are achieved in Gdańsk. The cities most polluted by road noise are Lublin—when analyzing a single full day—and Łódź, if only the night time is taken into account. These values range from $35-38 \%$

\subsubsection{Railroad Noise}

Similarly to the analyzed European cities, railway noise is a much smaller environmental problem in Polish cities, compared to road noise. Table 6 shows the percentage of inhabitants in selected Polish cities exposed to railway noise, with a distinction between $\mathrm{L}_{\mathrm{DWN}}$ and $\mathrm{L}_{\mathrm{N}}$ indicators. 
Table 6. The number of inhabitants in selected Polish cities exposed to railway noise, divided into appropriate ranges with a distinction between $\mathrm{L}_{\mathrm{DWN}}$ and $\mathrm{L}_{\mathrm{N}}$ indicators.

\begin{tabular}{|c|c|c|c|c|c|c|c|c|}
\hline \multirow{2}{*}{ City } & \multicolumn{4}{|c|}{ Percentage of Population Exposed to Noise per day, $\mathrm{L}_{\mathrm{DWN}}[\mathrm{dB}]$} & \multicolumn{4}{|c|}{ Percentage of Inhabitants Exposed to Noise at Night $L_{N}[d B]$} \\
\hline & $50-59$ & $60-64$ & $65-69$ & $70-74$ & $50-55$ & $55-59$ & $60-64$ & $65-69$ \\
\hline Warsaw & $0.56 \%$ & $0.19 \%$ & $0.04 \%$ & $0.00 \%$ & $0.35 \%$ & $0.10 \%$ & $0.01 \%$ & $0.00 \%$ \\
\hline Cracow & $1.42 \%$ & $0.39 \%$ & $0.10 \%$ & $0.00 \%$ & $1.04 \%$ & $0.28 \%$ & $0.04 \%$ & $0.00 \%$ \\
\hline Łódź & $0.74 \%$ & $0.30 \%$ & $0.07 \%$ & $0.00 \%$ & $0.61 \%$ & $0.23 \%$ & $0.04 \%$ & $0.00 \%$ \\
\hline Wrocław & $1.60 \%$ & $0.60 \%$ & $0.21 \%$ & $0.05 \%$ & $1.16 \%$ & $0.43 \%$ & $0.11 \%$ & $0.02 \%$ \\
\hline Poznań & $0.51 \%$ & $0.18 \%$ & $0.04 \%$ & $0.00 \%$ & $0.27 \%$ & $0.08 \%$ & $0.02 \%$ & $0.00 \%$ \\
\hline Gdańsk & $1.38 \%$ & $0.65 \%$ & $0.19 \%$ & $0.04 \%$ & $1.25 \%$ & $0.41 \%$ & $0.13 \%$ & $0.02 \%$ \\
\hline Lublin & $0.88 \%$ & $0.24 \%$ & $0.03 \%$ & $0.03 \%$ & $0.41 \%$ & $0.06 \%$ & $0.00 \%$ & $0.03 \%$ \\
\hline Bydgoszcz & $0.76 \%$ & $0.21 \%$ & $0.03 \%$ & $0.00 \%$ & $0.52 \%$ & $0.09 \%$ & $0.00 \%$ & $0.00 \%$ \\
\hline Białystok & $0.27 \%$ & $0.13 \%$ & $0.00 \%$ & $0.00 \%$ & $0.24 \%$ & $0.03 \%$ & $0.00 \%$ & $0.00 \%$ \\
\hline Katowice & $1.38 \%$ & $0.64 \%$ & $0.14 \%$ & $0.00 \%$ & $1.18 \%$ & $0.44 \%$ & $0.03 \%$ & $0.00 \%$ \\
\hline
\end{tabular}

When analyzing the data in Table 6, it can be concluded that the percentage of inhabitants exposed to railway noise does not exceed $2 \%$ in all analyzed cities. Two groups of cities can be specified based on the collected data. Gdańsk, Wrocław, Katowice, and Cracow are in the first group, more polluted by noise from train traffic. The percentage of the number of people exposed to this type of noise in these cities is over $0.5 \%$, taking into account $24 \mathrm{~h}$ a day and more than $1.0 \%$ at night. The second group is made up of the remaining cities and the percentages are lower than these values. As in the case of the European capital analysis, based on Tables 5 and 6, in Poland, it can also be unequivocally concluded that railway noise constitutes a much lower environmental risk than traffic noise.

The number of people exposed to a high degree of sleep disorders was calculated taking into account the health considerations of the inhabitants of the analyzed Polish cities. Most people are exposed to noise at night, at 50-55 dB. However, the number of people suffering from high-level sleep disturbances caused by noise exceeding $60 \mathrm{~dB}$ is not greater than 50 in every city. Wrocław has the worst position in this list, compared to other cities. Over 410 people living in the capital of Lower Silesia may suffer from sleep problems caused by railway noise. Other agglomerations include Cracow with almost 380 people, Gdańsk with over 320 people, and Warsaw with less than 300 people. The city of Białystok, where the number of inhabitants exposed to a high degree of sleep disorders is less than 30 , is the least affected by this problem. The foregoing data refer to the number of people in the entire city area. The entire list is presented in Figure 3.
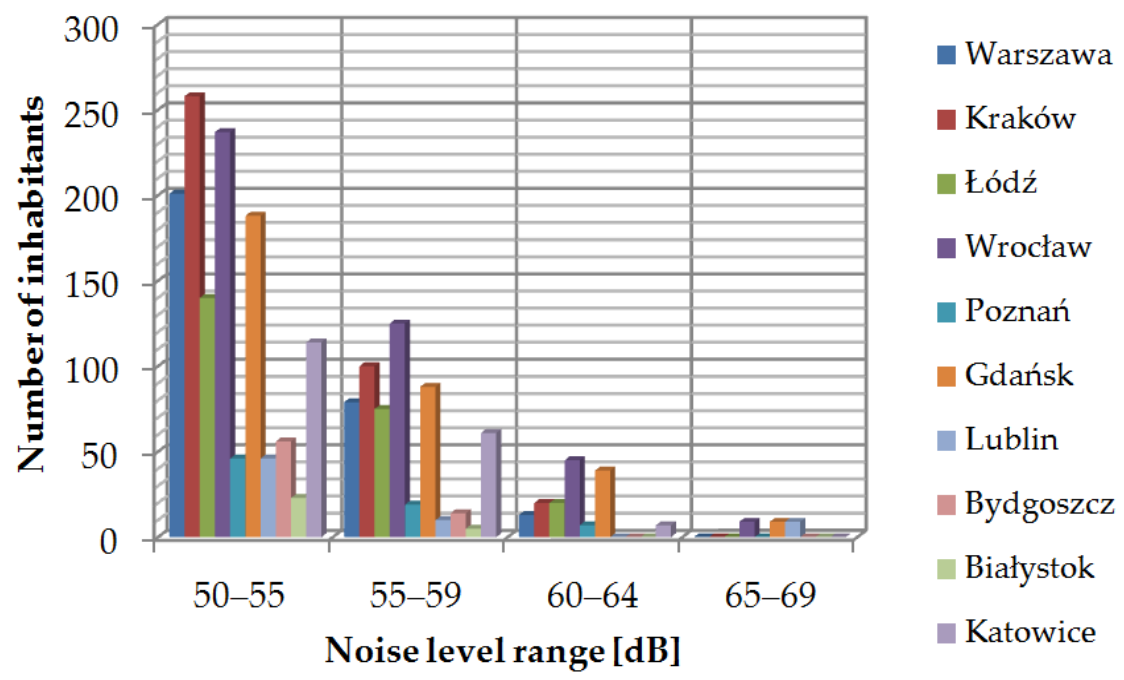

Figure 3. Number of inhabitants exposed to a high level of sleep disturbances caused by railway noise in selected Polish agglomerations.

For the analyzed cities in Poland, as in the case of European cities, an attempt was made to find the relationship between the $\mathrm{M}$ indicator and population density. As can be seen in Figure 4, those relations are not completely present. The $\mathrm{M}$ indicator takes the highest values for the city of Wrocław, but the 
population density in that city is not the highest in the analyzed agglomerations. The most densely populated cities include Warsaw and Bialystok, however, in case of these cities, the $\mathrm{M}$ indicator is lower than for the aforementioned Wroclaw. Interestingly, in the case of Białystok, the $\mathrm{M}$ indicator reaches the lowest values in this comparison, but in terms of population density in the city, it is surpassed only by the Polish capital, Warsaw.
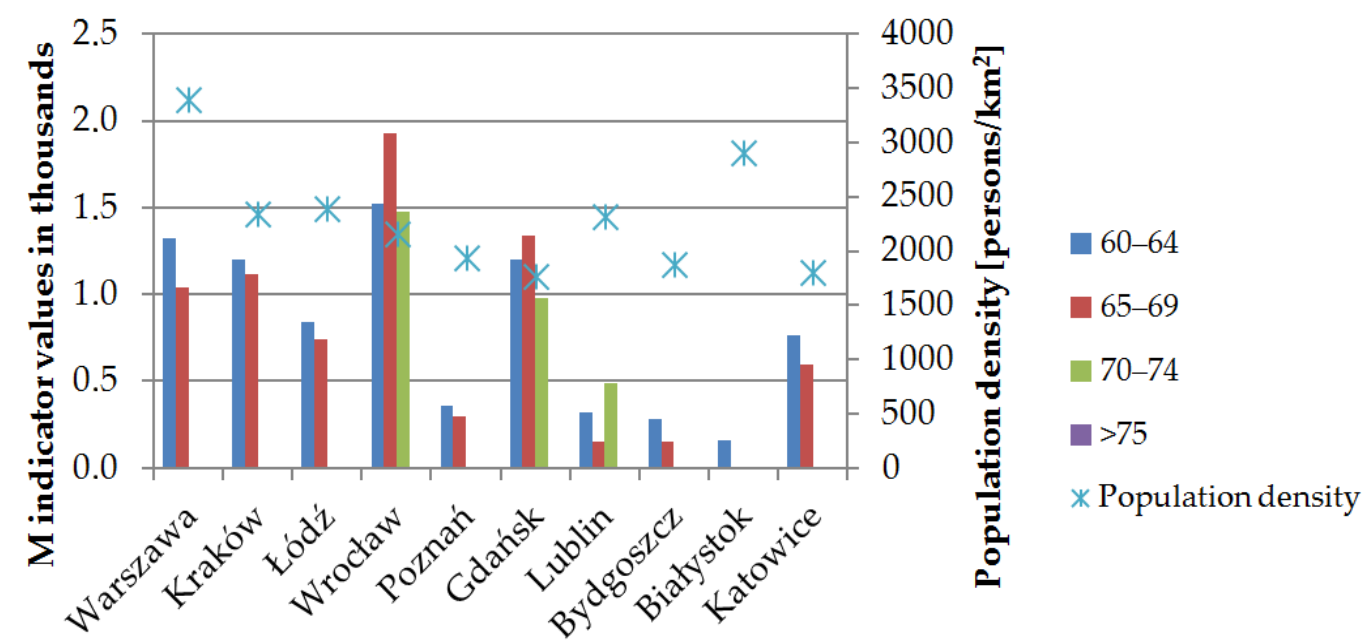

\section{Agglomeration in Poland}

Figure 4. Comparison of the $\mathrm{M}$ indicator for railway noise in selected Polish agglomerations, taking into account the population density in those cities.

The $\mathrm{M}$ indicator described in formula (10) takes only two variables into account, therefore an important direction of further research will be to look for indicators that include more factors influencing the number of people exposed to traffic noise.

\section{Discussion}

The phenomenon of railway noise is an extremely complex issue, and much more complicated than road transport noise. The emission of railway noise depends on numerous factors. This is influenced by e.g., the technical condition of the tracks and rolling stock, the type of brakes used, the traffic volume, or the terrain. As in road traffic, in rail traffic, the noise level is determined mainly by freight depots. In the case of some cities with a highly developed rail network, passenger traffic is a factor that can cause significant effects. Gdańsk, relying heavily on rail transport, which is a kind of transport pillar of the city, is one such example of a city. In Bydgoszcz, on the other hand, railway lines bypass the city center, and the main railway transport type is freight transport. The French capital of Paris, with its very well developed rail network within the city, can be an example of a European city with dominant passenger traffic.

At the moment, there is also a systematic decrease in the distance between buildings and railway lines, mainly residential buildings. It is therefore worth analyzing other factors that may affect the number of people exposed to rail noise in cities.

One of the basic factors to be analyzed is undoubtedly the length of railway lines within city limits. These data are shown in Table 7. 
Table 7. Comparison of basic data for selected cities.

\begin{tabular}{cccccc}
\hline City & $\begin{array}{c}\text { Population } \\
\text { Density } \\
\text { [persons/km }\end{array}$ & $\begin{array}{c}\text { Length of Railway } \\
\text { Lines [km] }\end{array}$ & $\begin{array}{c}\text { Number of } \\
\text { Railway } \\
\text { Stations/Stops }\end{array}$ & $\begin{array}{c}\text { Presence of } \\
\text { Railway Lines } \\
\text { in the Center }\end{array}$ & $\begin{array}{c}\text { Length of Railway Lines } \\
\text { Running through } \\
\text { Forest/Unbuilt-Up Area [km] }\end{array}$ \\
\hline Warsaw & 3391 & 110 & 46 & + & 2.9 \\
Cracow & 2346 & 122.5 & 24 & + & 12.0 \\
Łódź & 2392 & 161.3 & 18 & - & 8.1 \\
Wrocław & 2156 & 178 & 24 & + & 11.0 \\
Poznań: & 1936 & 161.3 & 15 & + & 7.0 \\
Gdańsk & 1770 & 48.5 & 17 & + & 6.0 \\
Lublin & 2314 & 43.6 & 8 & - & 18.4 \\
Bydgoszcz & 1870 & 64.2 & 14 & + & 5.4 \\
Białystok & 2905 & $32.2 *$ & 8 & + & 15.0 \\
Katowice & 1796 & $101 *$ & 9 & + & \\
\hline \multicolumn{7}{r}{}
\end{tabular}

It can be assumed that the longer the length of railway lines in the city, the greater the scale of exposure to noise from rail transport [28,29]. However, it is also necessary to analyze the areas where the railway lines run and the buildings along them.

Cities such as Wrocław, Cracow, Łódź, and Poznań have the most developed railway network. In the case of Wrocław and Cracow, this is reflected by the highest number of people exposed to railway noise. In both agglomerations, the main railway stations and the highly developed railway network around them are located in the central part of the city, where the building placement is the most dense. Figures 5 and 6 show the land use in the vicinity of the main stations in these cities. The centers of large cities are mostly characterized by compact building placement and, consequently, a large number of inhabitants in the area.

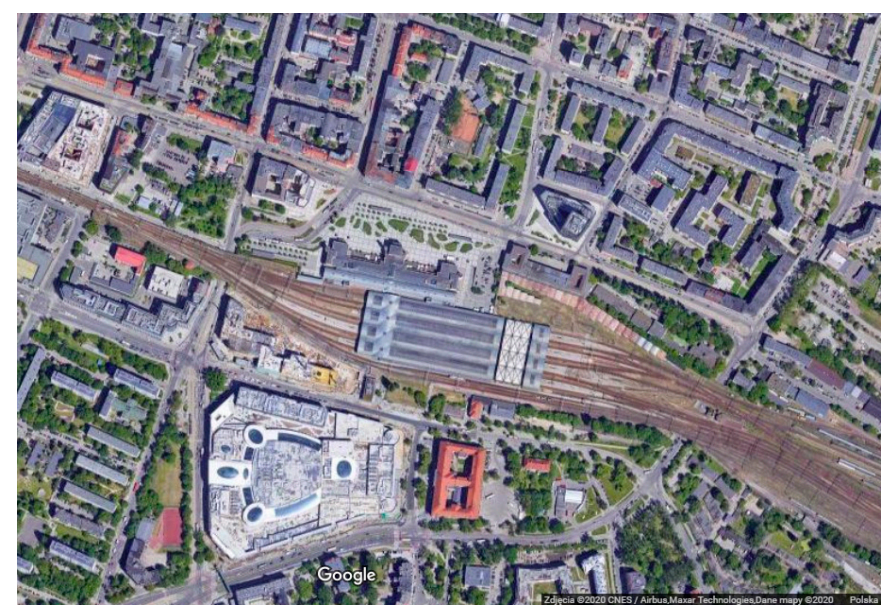

Figure 5. Buildings near the Main Railway Station in Wrocław.

On the other hand, in Łódź, the railway lines bypass the strict center, but one can observe dense building placement most often along their route, in the form of blocks of flats and single-family houses. In many locations, however, it is separated by a wide band of high greenery, which has a positive effect on the number of people affected by this type of noise. This situation is illustrated in Figure 7.

In comparison to the aforementioned cities, Poznan is characterized by a small number of inhabitants exposed to noise annoyance. This may be justified mainly by dispersed single-family buildings along railway lines. In addition, a large part of the network runs on unbuilt-up areas and forest areas.

The capital city of Poland, Warsaw, is also one of the cities most polluted by railway noise. This agglomeration is characterized by dense of pattern of single-family houses and blocks of flats, along the railway network, and it is a compact building pattern in the center. It also has the largest 
number of stations and stops among the analyzed cities (Table 7), which generates additional noise when braking and starting the rolling stock. Moreover, Warsaw has the highest population density.

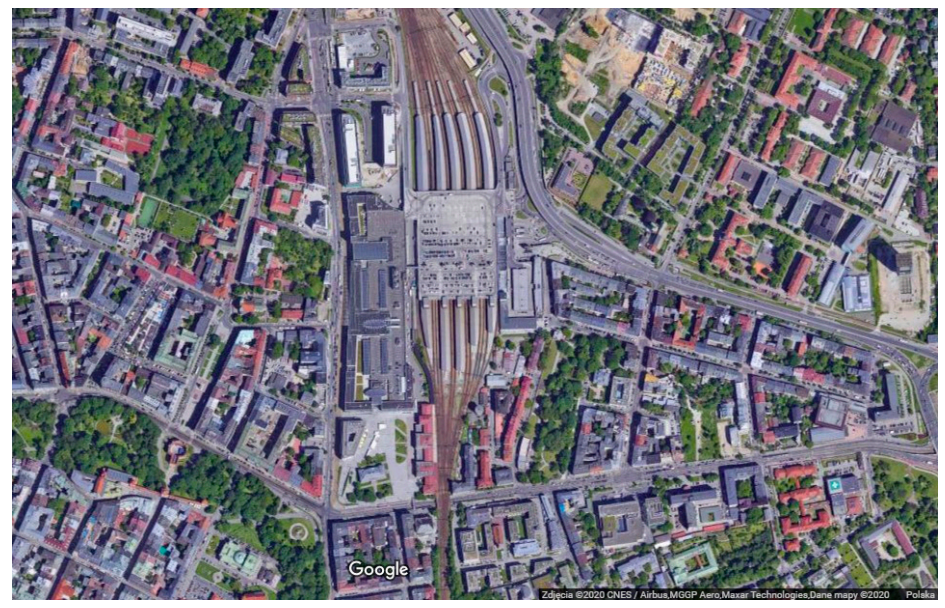

Figure 6. Buildings near the Kraków Main Railway Station in Cracow.

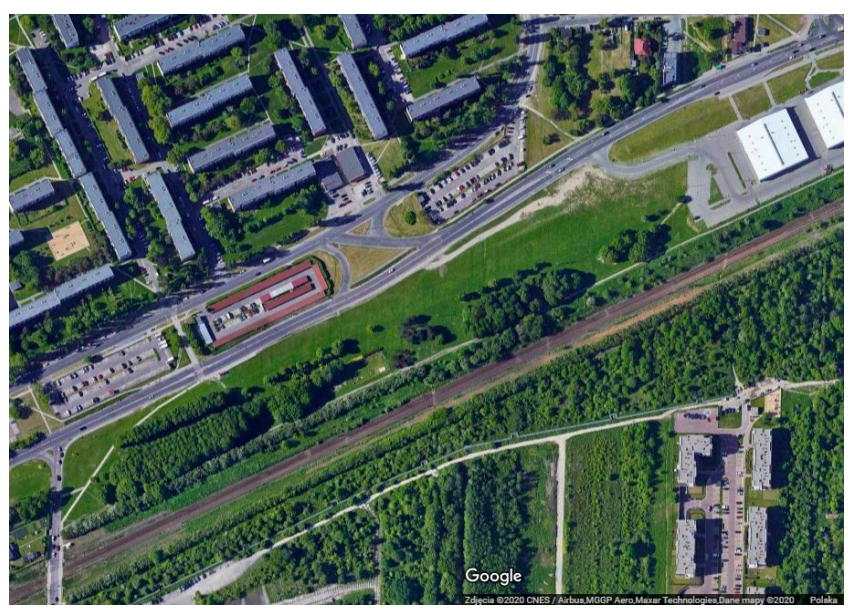

Figure 7. A fragment of the railway line in Łódź.

Interestingly, in terms of the length of railway lines within the city, Gdańsk is at the end of the list, and yet the number of people exposed to noise from train traffic is high. This may be explained by the fact that the main railway line is densely covered by the estates of single-family houses and housing developments with blocks of flats, and additionally the main railway station is located in the very center of the city.

The cities of Białystok, Bydgoszcz, and Lublin have a much less developed railway network, and in addition, the city centers are bypassed by railways in Lublin and Bydgoszcz. Dispersed estates of single-family houses along the existing tracks dominate in these agglomeration, and a large part runs through forests and unbuilt-up areas.

\section{Conclusions}

In terms of the environmental factors that disrupt human activity, people most often complain about noise emitted by airplane, road, and railway traffic [30]. Numerous studies have shown that the same noise level is less annoying in areas where rail noise dominates, compared to the road traffic noise [31]. Road and railway noise vary significantly due to their nature (size, impact time, etc.). Road traffic mostly causes continuous noise, while railway noise is intermittent. Railway transport can be one of the solutions to congestion and pollution problems, but the disadvantage of rail includes 
generated noise, as well as accompanying vibrations. Nevertheless, in recent years, the use of this mode of transport has increased, and there has been a rapid increase in the number of tramway and high-speed rail track projects $[32,33]$.

The article analyzes data on the number of people exposed to noise from road and railway traffic. The results of the study are derived from the compilation of strategic noise maps for European agglomerations in accordance with the guidelines contained in the END Directive [8]. Unfortunately, it was not possible to include all major European cities in the foregoing analysis due to data gaps in some reports. Moreover, it is very problematic to compare the analyzed results with data from previous phases of strategic acoustic mapping. This problem is caused by differences in databases concerning the number of analyzed sections due to different qualification of measurement areas. In the first round, measurements were performed in 12 cities in Poland, with 39 in the second round, and 35 in the third one [13].

This article included an analysis of selected nine European capitals, in which large differences were observed in the percentage of inhabitants exposed to road and rail noise. Vienna is the most noise-polluted city in the world, and this applies to noise from road traffic, as well as rail traffic. However, among the analyzed European agglomerations, Berlin is the city least polluted by road noise, and Warsaw is the least affected by railway noise. When analyzing only cities in Poland, the differences in the percentage of inhabitants exposed to noise were much smaller.

Systematic research and strategic noise mapping are important as they allow to determine the existing state of environmental noise pollution, and to prepare programs of environment protection against noise, aimed e.g., at indicating protective measures. These measures can be aimed at reducing this negative impact by using appropriate acoustic protection. It also allows to determine the order of actions, i.e., the locations where excessive levels are the greatest should be given priority. Due to the different land development along roads and railways, it is not possible to apply a single type of noise protection. This provides an opportunity for further analysis and actions in this area.

One of the advantages of the methodology presented in the article is basing the analyses and conclusions on the actual number of people exposed to noise, with values that adversely affect their health. By making strategic acoustic maps in the EU countries, performed with the same methodology, it is possible to directly compare the results between Member States.

The insufficient number of indicators taking into account various factors and the problem of incomplete data provision by all Member States is a clear disadvantage of the presented methodology. It is necessary to look for indicators that take more variables into account, other than the M (10) indicator described, and which provide better characteristics of the rail noise problem. The identification of new indicators can help in the process of planning new routes on a city scale, e.g., to compare route options. This is undoubtfully an opportunity for further research.

Author Contributions: Methodology, J.B. and M.W.; Investigation, M.W. and J.B.; Resources, M.W. and J.B.; Writing-Original Draft Preparation, M.W.; Writing_-Review \& Editing, J.B. and M.W.; Supervision, J.B.; Funding Acquisition, J.B. All authors have read and agreed to the published version of the manuscript.

Funding: The article was written as part of the POIR.04.01.04-00-0078/18 "Nowe rozwiazanie podkładki podpodkładowej i tłumika szynowego do ochrony otoczenia drogi szynowej przed drganiami i hałasem" research project.

Conflicts of Interest: The authors declare no conflict of interest.

\section{References}

1. Babisch, W.; Swart, W.; Houthuijs, D.; Selander, J.; Bluhm, G.; Pershagen, G.; Dimakopoulou, K.; Haralabidis, A.S.; Katsouyanni, K.; Davou, E.; et al. Exposure modifiers of the relationships of transportation noise with high blood pressure and noise annoyance. J. Acoust. Soc. Am. 2012, 132, 3788-3808. [CrossRef] [PubMed]

2. Brown, A.L. Effects of road traffic noise on health: From burden of disease to effectiveness of interventions. Procedia Environ. Sci. 2015, 30, 3-9. [CrossRef] 
3. Camusso, C.; Pronello, C. A study of relationships between traffic noise and annoyance for different urban site typologies. Transp. Res. Part D Transp. Environ. 2016, 44, 122-133. [CrossRef]

4. D'Alessandro, F.; Schiavoni, S. A review and comparative analysis of European priority indices for noise action plans. Sci. Total Environ. 2015, 518, 290-301. [CrossRef] [PubMed]

5. European Environmental Agency. Good Practice Guide on Noise Exposure and Potential Health Effects; EEA Technical Report No. 11/2010; European Environment Agency: Copenhagen, Denmark, 2010.

6. World Health Organization. Environmental Noise Guidelines for the European Region; World Health Organization: Geneva, Switzerland, 2018.

7. Selander, J.; Nilsson, M.E.; Bluhm, G.; Rosenlund, M.; Lindqvist, M.; Nise, G.; Pershagen, G. Long-Term Exposure to Road Traffic Noise and Myocardial Infarction. Epidemiology 2009, 20, 272-279. [CrossRef] [PubMed]

8. European Commission. Directive 2002/49/EC of the European Parliament and of the Council of 25 June 2002 Relating to the Assessment and Management of Environmental Noise. Available online: https: //eur-lex.europa.eu/legal-content/EN/TXT/?uri=CELEX\%3A32002L0049 (accessed on 12 July 2020).

9. Arana, M.; Martin, R.S.; Salinas, J.C. People exposed to traffic noise in european agglomerations from noise maps. A critical review. Noise Mapp. 2014, 1, 40-49. [CrossRef]

10. King, E.; Murphy, E. Environmental noise-'Forgotten' or 'Ignored' pollutant? Appl. Acoust. 2016, 112, 211-215. [CrossRef]

11. King, E.; Murphy, E.; Rice, H. Implementation of the EU environmental noise directive: Lessons from the first phase of strategic noise mapping and action planning in Ireland. J. Environ. Manag. 2011, 92, 756-764. [CrossRef] [PubMed]

12. Rozporządzenie Ministra Środowiska z dnia 1 października 2007 r. w sprawie szczegółowego zakresu danych objętych na mapach akustycznych oraz ich układu i sposobu prezentacji. Available online: http: //isap.sejm.gov.pl/isap.nsf/DocDetails.xsp?id=WDU20071871340 (accessed on 12 July 2020).

13. Noise Exposure Information under the END Directive (2002/49/EC). Available online: https://www.eea. europa.eu/data-and-maps/data/data-on-noise-exposure-7/noise-exposure-information-under-the (accessed on 30 January 2020).

14. Kephalopoulos, S.; Paviotti, M.; Anfosso-Lédée, F. Common Noise Assessment Methods in Europe (CNOSSOS-EU); EUR 25379 EN; Publications Office of the European Union: Luxembourg, 2012.

15. Bruel, P.V. Is A-weighting of noise correct? InterNoise 2001, 2001, 1521-1524.

16. Kjellberg, A.; Goldstein, M.; Gamberale, F. An assessment of $\mathrm{dB}(\mathrm{A})$ for predicting loudness and annoyance of noise containing low frequency noise. J. Low Freq. Noise Vib. 1984, 3, 10-16. [CrossRef]

17. Muzet, A. Environmental noise, sleep and health. Sleep Med. Rev. 2007, 11, 135-142. [CrossRef] [PubMed]

18. Perron, S.; Plante, C.; Ragettli, M.S.; Kaiser, D.J.; Goudreau, S.; Smargiassi, A. Sleep disturbance from road traffic, railways, airplanes and from total environmental noise levels in montreal. Int. J. Environ. Res. Public Health. 2016, 13, 809. [CrossRef] [PubMed]

19. Miedema, H.M.; Oudshoorn, C.G. Annoyance from transportation noise: Relationships with exposure metrics DNL and DENL and their confidence intervals. Environ. Health Perspect. 2001, 109, 409-416. [CrossRef] [PubMed]

20. Park, T.; Kim, M.; Jang, C.; Choung, T.; Sim, K.-A.; Seo, D.; Chang, S.I. The Public Health Impact of Road-Traffic Noise in a Highly-Populated City, Republic of Korea: Annoyance and Sleep Disturbance. Sustainability 2018, 10, 2947. [CrossRef]

21. Bohatkiewicz, J. Modelowanie i ocena rozwiąań chroniacych przed hałasem drogowym; Politechnika Lubelska: Lublin, Poland, 2017.

22. European Communities. Position Paper on Dose Response Relationships between Transportation Noise and Annoyance; European Communities: Luxembourg, 2002.

23. World Health Organization. Night Noise Guidelines for Europe; WHO Regional Office for Europe: Copenhagen, Denmark, 2009.

24. Obwieszczenie Ministra Środowiska z dnia 15 października 2013 r. w sprawie ogłoszenia jednolitego tekstu rozporządzenia Ministra Środowiska w sprawie dopuszczalnych poziomów hałasu w środowisku (Dz. U. z 2014 r., poz. 112). Available online: http://isap.sejm.gov.pl/isap.nsf/DocDetails.xsp?id=WDU20140000112 (accessed on 12 July 2020). 
25. Rozporządzenie Ministra Środowiska z dnia 1 października 2012 r. zmieniajace rozporządzenie w sprawie dopuszczalnych poziomów hałasu w środowisku (Dz. U. z 2012 r., poz. 1109). Available online: http: //isap.sejm.gov.pl/isap.nsf/DocDetails.xsp?id=WDU20120001109 (accessed on 12 July 2020).

26. The Noise Observation \& Information Service for Europe. Available online: http://noise.eea.europa.eu/ (accessed on 30 January 2020).

27. Rozporządzenie Ministra Środowiska z dnia 16 czerwca 2011 r. w sprawie wymagań w zakresie prowadzenia pomiarów poziomów substancji lub energii w środowisku przez zarządzającego drogą, linią kolejowa, linią tramwajowa, lotniskiem lub portem (Dz. U. 2011 nr 140 poz. 824). Available online: http://isap.sejm.gov.pl/ isap.nsf/DocDetails.xsp?id=WDU20111400824 (accessed on 12 July 2020).

28. Connolly, D.P.; Marecki, G.P.; Kouroussis, G.; Woodward, P.K. The growth of railway ground vibration problems-A review. Sci. Total Environ. 2016, 568, 1276-1282. [CrossRef] [PubMed]

29. Kaewunruen, S.; Martin, V. Life Cycle Assessment of Railway Ground-Borne Noise and Vibration Mitigation Methods Using Geosynthetics, Metamaterials and Ground Improvement. Sustainability 2018, 10, 3753. [CrossRef]

30. Kaewunruen, S. Monitoring of rail corrugation growth on sharp curves for track maintenance prioritization. Int. J. Acoust. Vib. 2018, 23, 35-43.

31. Fields, J.M.; Walker, J.G. Comparing the relationships between noise level and annoyance in different surveys: A railway noise vs. aircraft and road traffic comparison. J. Sound Vib. 1982, 81, 51-80. [CrossRef]

32. Kouroussis, G.; Connolly, D.P.; Verlinden, O. Railway-induced ground vibrations-A review of vehicle effects. Int. J. Rail Transp. 2014, 2, 69-110. [CrossRef]

33. Bunn, F.; Zannin, P.H.T. Assessment of railway noise in an urban setting. Appl. Acoust. 2016, 104, $16-23$. [CrossRef]

(C) 2020 by the authors. Licensee MDPI, Basel, Switzerland. This article is an open access article distributed under the terms and conditions of the Creative Commons Attribution (CC BY) license (http://creativecommons.org/licenses/by/4.0/). 